\title{
Effects of Harvesting Mucuna bracteata on the Legume Biomass and Soil Properties under Mature Oil Palm
}

\author{
Mohd Amir Zunnasri Mohd Noor ${ }^{1}$, Muhammad Firdaus Sulaiman', Wan Azlina \\ Wan Abdul Karim Ghani ${ }^{2}$ and Christopher Boon Sung Teh ${ }^{1 *}$ \\ ${ }^{1}$ Department of Land Management, Faculty of Agriculture, Universiti Putra Malaysia, \\ 43400 Serdang, Selangor, Malaysia \\ ${ }^{2}$ Department of Chemical and Environmental Engineering, Faculty of Engineering, \\ Universiti Putra Malaysia, 43400 Serdang, Selangor, Malaysia
}

\begin{abstract}
The under-utilized legume Mucuna bracteata is a potential biomass resource in Malaysia. A 24-month study was conducted under 10-year-old mature oil palm trees to determine the effects of several harvesting frequencies of $M$. bracteata on the legume biomass and soil properties. The experimental design was a randomized complete block design (RCBD) for the biomass and a two-factorial RCBD for the soil properties. The treatments were the harvesting frequencies, which were once every two, four, six, and twelve months. The control treatment was without harvest. There were significant effects on the legume's cumulative biomass, standing biomass, leaf area, nutrient contents, and total nutrient harvested for $\mathrm{N}, \mathrm{Ca}, \mathrm{Mg}$, and cellulose content. Generally, the more frequent the harvest, the more biomass was obtained, but the more legume standing biomass and leaf area were reduced. Despite the reduction in legume growth and leaf area in the field, harvesting the legume did not affect any of the soil physicochemical properties. The biomass $\mathrm{N}, \mathrm{Ca}$, and $\mathrm{Mg}$ contents and nutrient

ARTICLE INFO

Article history:

Received: 30 April 2020

Accepted: 07 September 2020

Published: 24 February 2021

DOI: https://doi.org/10.47836/pjtas.44.1.08

$\overline{\text { E-mail addresses: }}$

mohdamirzunnasri@gmail.com

(Mohd Amir Zunnasri Mohd Noor)

muhdfirdaus@upm.edu.my (Muhammad Firdaus Sulaiman) wanazlina@upm.edu.my (Wan Azlina Wan Abdul Karim Ghani)

chris@upm.edu.my (Christopher Boon Sung Teh)

* Corresponding author harvested were also affected by harvesting. This was due to the production of relatively more young shoots after harvesting, which would remove most of the aboveground plant parts. The cellulose content in the legume also increased for the same reasons. Results showed that harvesting M. bracteata once every six months was an acceptable compromise between collecting large
\end{abstract}


amounts of legume biomass and having a reduced legume growth recovery and leaf area in the field, but yet not detrimentally affecting the soil properties.

Keywords: Biomass quality, legume, Mucuna bracteata, soil conservation, soil nutrient

\section{INTRODUCTION}

Malaysia produced about 168 million tons of agricultural wastes in 2007, and the production of the biomass increases every year. These biomass resources are from oil palm, rubber, rice, horticulture, coconut, and orchard (C. S. Goh et al., 2010). However, most of the biomass (more than $90 \%$ ) is from oil palm. Being the fourth largest contributor to the Malaysian's Gross National Income (GNI) and generating billions of revenue (Agensi Inovasi Malaysia [AIM], 2013), oil palm industries have been reported to produce 50 to 70 million tons of solid and liquid biomass in 2007 (Shuit et al., 2009), which further increased to 60 to 83 million tons of biomass in 2012. The biomass production of oil palm industries is expected to further increase to between 85 - 110 million tons by this year 2020 (AIM, 2013). Agriculture biomass has multiple uses, such as for renewable energy (Lior, 2008), bio-based materials in furniture, building materials, electronics, packaging, automobile industries, and value-added products (such as animal food, fertilizers, absorbent, as well as pulp and paper) (Abdul Khalil et al., 2009, 2010; Chaikitkaew et al., 2015).
For these reasons, Malaysia is interested in finding sources for biomass. The Malaysian Biomass Initiatives (MBI) was established on 9th May 2012 to support the national vision to increase biomass usage and encourage the growth and adaptation of green technologies in the country. This effort and support from the government are part of the many national policies, such as National Green Technology Policy 2009, Economic Transformation Programme 2010, Renewable Energy Act 2011, National Biomass Strategy 2020, and Malaysia Biomass Industry Action Plan 2020.

Among the potential biomass supplementation to oil palm is Mucuna bracteata DC. ex Kurz, and the potential of its use is substantial. Mucuna bracteata is under-utilized because this leguminous plant is currently grown only as a cover crop in oil palm plantations since its introduction in Malaysia in 1991 (Mathews, 1998). This legume grows fast (new shoots regrow approximately after 30 days), is tolerant to drought (can survive up to four months), and shade tolerant, as well as quick to produce thick and uniform cover compared to other conventional leguminous cover crops namely, Pueraria phaseoloides (Pueraria javanica), Centrosema pubescens, Calopogonium mucunoides, and Calopogonium caeruleum (Chiu et al., 2001). In addition, M. bracteata experiences less pest infestation and disease attacks, and the legume is non-palatable to cattle due to high content of phenolic compounds (Kothandaraman et al., 1989). 
Considering $M$. bracteata's rapid growth and high biomass yield, it is desirable if this legume, in addition to its role as a cover crop to protect and conserve soil, can act as a source of biomass that could be harvested regularly. Unfortunately, much less is known about the quality and quantity of $M$. bracteata coupled with or without harvesting effects after several frequencies because the use of this legume as a biomass resource in Malaysia and the effects of harvesting have not been explored. The only study was by Chiu and Basad (2006) that showed that fully established $M$. bracteata was tolerant to repeated cutting at bimonthly intervals. Most studies emphasized on the soil properties (for e.g., chemical, physical, and biological), soil erosions and runoff, soil water, suppressing noxious weeds, pest control (Rhinocerous orycite) as well as agronomic and the economic planting of $M$. bracteata. Therefore, this study was carried out with the general objective to determine the effect of frequent harvesting of $M$. bracteata on the legume and soil properties. The specific objectives were: (i) to determine the suitability of $M$. bracteata above ground parts as a biomass resource regarding on its quantity and quality properties, (ii) to determine the cumulative and standing biomass weights of $M$. bracteata after being harvested at several harvesting frequencies, and (iii) to determine whether $M$. bracteata can remain as an effective cover crop under oil palm to maintain soil fertility even after being harvested.

\section{MATERIALS AND METHODS}

\section{Study Site and Soil Profile Background}

The study was carried out at Kombok Estate, Rembau, Negeri Sembilan $\left(2.6216^{\circ}\right.$ $\left.\mathrm{N} 101.9836^{\circ} \mathrm{E}\right)$ on Durian series soil. According to the Food and Agriculture Organization (FAO) classification, the Durian series is classified as Plinthaquic, clayey, mixed, isohyperthermic, Ferric Acrisol. The soil was developed from sedimentary and low-grade metamorphic rocks. According to Department of Agriculture (DoA) (2008), this soil series is considered suitable for oil palm (Elaeis guineensis), cocoa (Theobromae cocoa), rubber (Hevea brasiliensis), coconut (Cocos nucifera), and fruits, as well as short term crops, and this soil has moderate nutrient contents. This soil is normally located on undulating terrain with a CEC range of 5 $10 \mathrm{cmol}_{+} \mathrm{kg}^{-1}$, and the colour of this soil is yellowish brown (10YR 5/4, 5/6, 5/8). The soil at this experimental site was measured as having a clay texture, with a mean $( \pm$ std. error) of $43.4 \pm 0.30 \%$ clay and $25.3 \pm$ $0.17 \%$ sand.

\section{Fertilizer Management and Rainfall at the Study Site}

The fertilization routine carried out in the mature oil palm area is under Applied Agricultural Resources (AAR) Sdn. Bhd. The fertilizers used were OPCOM 65 and Fertibor (Table 1). OPCOM 65 is a compound fertilizer that contains $13.65 \%$ ammonium sulphate, $0.99 \%$ rock phosphate, and $19.2 \%$ potassium chloride that provides nitrogen $(\mathrm{N})$, phosphorus $(\mathrm{P})$, and potassium 
$(\mathrm{K})$, respectively. Fertibor is a straight fertilizer that provides approximately $15 \%$ of B. The study was conducted from March 2015 to March 2017. Before the study was conducted, the application of fertilizer had been conducted in February 2015 with the dosage between 2.00 and $2.25 \mathrm{~kg}^{\text {palm }}$ ${ }^{1}$ (OPCOM 65). The routine continued into May, August, and September for the years 2015 and 2016, and the oil palm was supplemented with $0.10 \mathrm{~kg} \mathrm{palm}^{-1}$ of Fertibor in July.

Table 1

Type, month, and rate of application of fertilizers in year 2015 and 2016

\begin{tabular}{llcc}
\hline \multirow{2}{*}{ Fertilizer type } & \multirow{2}{*}{$\begin{array}{l}\text { Month of } \\
\text { application }\end{array}$} & \multicolumn{2}{c}{ Rate $\left(\mathrm{kg} \mathrm{palm}^{-1} \mathrm{yr}^{-1}\right)$} \\
\cline { 3 - 4 } & 2015 & 2016 \\
\hline OPCOM 65 & February & 2.00 & 2.25 \\
OPCOM 65 & May & 2.00 & 2.25 \\
Fertibor & July & 0.10 & 0.10 \\
OPCOM 65 & August & 2.00 & 2.25 \\
OPCOM 65 & September & 2.25 & 2.00 \\
\hline
\end{tabular}

Table 2

Monthly $\left(\mathrm{mm} \mathrm{month}^{-1}\right)$ and annual $\left(\mathrm{mm} \mathrm{yr}^{-1}\right)$ rainfall in year 2015 and 2016

\begin{tabular}{lll}
\hline Month & 2015 & 2016 \\
\hline January & 144 & 159 \\
February & 38 & 141 \\
March & 136 & 55 \\
April & 306 & 169 \\
May & 94 & 209 \\
June & 128 & 214 \\
July & 42 & 192 \\
August & 87 & 95 \\
September & 116 & 115 \\
October & 164 & 181 \\
November & 260 & 74 \\
December & 328 & 153 \\
\hline Total & 1843 & 1757 \\
\hline
\end{tabular}

The rainfall distribution in the area was very variable (Table 2 ). In particular, due to the El Nino phenomenon between midDecember 2015 and mid-April 2016, there was a large decline in rainfall during those months, with monthly rainfall of between 55 and $328 \mathrm{~mm}$. This directly affected the average rainfall distribution in a year, and subsequently, detrimentally affected the quantity of legume biomass.

\section{Experimental Units and Designs}

Mucuna bracteata was already planted and established under the oil palm ( 8 to 10 years) before the field experiment. The experimental designs in the study were: (i) randomized completely block design (RCBD) for M. bracteata biomass, where the factor was the harvesting frequencies, and (ii) factorial RCBD for the soil parameters, where the factors were the harvesting frequencies and soil depths. There were five harvesting frequencies, where the first four harvesting frequencies were harvesting the legume once every: i) two (HF 2), ii) four (HF 4), iii) six (HF 6), and iv) twelve (HF 12) months. The fifth harvesting frequency was control (HF0), which did not involve any harvesting. Each harvesting treatment was replicated four times, and means comparisons were done for months 12 and 24. Soil properties were measured from two soil depths (0-15 and 15-30 cm).

\section{Sampling and Preparation of Mucuna bracteata Biomass}

In each sampling time, the leaves and stolon were harvested over a $1-\mathrm{m}^{2}$ area at $2 \mathrm{~cm}$ 
height above the soil surface. The sample was placed in a plastic bag, labelled, and brought to the laboratory. At the laboratory, the leaves and stolon were separated, cleaned thoroughly to remove the dirt and soil, and air-dried for 24 hours. The leaf blades were measured for the leaf area determination. The samples were then kept in carbon free envelops and oven-dried at $65^{\circ} \mathrm{C}$ for 5 days, then they were reweighed. The initial and final weights were used to determine the cumulative and standing biomass (Table 3).

The biomass were ground into 1-mm size using MK 10 basic IKA WERKE mill (IKA-Works Inc., USA) with 3,750 rpm, and then kept in dry screw-capped bottles to avoid ambient air moisture. Some ground samples were delivered to the Agriculture and Food Analytical Laboratory, Malaysian Agricultural Research and Development Institute (MARDI) for the determination of cellulose, hemicellulose, and lignin contents. All other analyses were done at the Material Characterization Lab, Department of Chemical and Environmental Engineering and Analytical Laboratory 2, Faculty of Engineering or the Department of Land Management, Faculty of Agriculture, Universiti Putra Malaysia.

The total harvested biomass nutrient $(\mathrm{kg}$ $\mathrm{ha}^{-1} \mathrm{yr}^{-1}$ ) was calculated via the following formula:

Total harvested biomass nutrient $=c / 100 \times w$

Table 3

Methods used to determine the quantitative and quality properties of Mucuna bracteata

\begin{tabular}{|c|c|}
\hline Property & Method \\
\hline $\begin{array}{l}\text { Cumulative dry weight }(\mathrm{t} \\
\left.\mathrm{ha}^{-1} \mathrm{yr}^{-1}\right)\end{array}$ & $\begin{array}{l}\text { Accumulation of } M \text {. bracteata biomass dry weight from all previous } \\
\text { harvests }\end{array}$ \\
\hline $\begin{array}{l}\text { Standing dry weight } \\
\left(\mathrm{t} \mathrm{ha}^{-1}\right)\end{array}$ & Mucuna bracteata current biomass dry weight in the field \\
\hline Leaf area $\left(\mathrm{m}^{2} \mathrm{~m}^{-2}\right)$ & $\begin{array}{l}\text { i. PAR Ceptometer (AccuPAR LP - 80, Decagon Devices Inc., USA) before } \\
\text { month } 8 \text { (Zarate-Valdez et al., 2012) } \\
\text { ii. LI-COR Leaf Area Meter (Model LI - } 3100 \text { C, LI-COR Inc., USA) } \\
\text { (Campostrini \& Yamanishi, 2001) at month } 8 \text { onwards }\end{array}$ \\
\hline $\mathrm{C}$ and $\mathrm{N}$ contents $(\%)$ & $\begin{array}{l}\text { Analyzed using LECO TruMac }{ }^{\circledR} \text { CNS Auto Analyzer Version 1.1x. (LECO } \\
\text { Corporation, USA) }\end{array}$ \\
\hline $\begin{array}{l}\mathrm{P}, \mathrm{K}, \mathrm{Ca} \text {, and } \mathrm{Mg} \text { contents } \\
(\%)\end{array}$ & $\begin{array}{l}\text { Standard established wet ashing method (Van Lierop, 1976) and analyzed } \\
\text { by XYZ Auto Sampler ASX - } 520 \text { Series (SD Acquisition, Inc., USA) } \\
\text { and PerkinElmer Atomic Absorption Spectrometer PinAAcle } \\
\text { (PerkinElmer Inc., USA) }\end{array}$ \\
\hline $\begin{array}{l}\text { Cellulose, hemicellulose, } \\
\text { and lignin contents }(\%)\end{array}$ & $\begin{array}{l}\text { Standard acid detergent fiber (ADF) and Standard acid detergent lignin } \\
\text { (ADL) assays (Saura-Calixto et al., 1983) }\end{array}$ \\
\hline $\begin{array}{l}\text { Ash content and volatile } \\
\text { matter }(\%)\end{array}$ & $\begin{array}{l}\text { Thermogravimetric analysis (TGA) (Idris et al., 2010) and analyzed by } \\
\text { METTLER TOLEDO TGA/SDTA 851e (METTLER TOLEDO, Canada) } \\
\text { (Ludwig et al., 2007) }\end{array}$ \\
\hline $\begin{array}{l}\text { Calorific value } \\
\left(\mathrm{MJ} \mathrm{kg}^{-1}\right)\end{array}$ & $\begin{array}{l}\text { Analyzed using IKA C2000 Bom Calorimeter (IKA }{ }^{\circledR} \text { Works Inc., USA) } \\
\text { (Gardner et al., 2015) }\end{array}$ \\
\hline
\end{tabular}


where $c$ is the biomass nutrient content (\%), and $w$ is the cumulative harvested biomass weight $\left(\mathrm{kg} \mathrm{ha}^{-1} \mathrm{yr}^{-1}\right)$.

\section{Sampling and Preparation of Soil}

The soils were sampled for the chemical and physical parameters, as shown in Table 4. Two hundred and fifty grams of soil were sampled at each of two soil depths: $0-15$ and $15-30 \mathrm{~cm}$ in a $1-\mathrm{m}^{2}$ area at sampling times once after every 2, 4, 6, and 12 months, meanwhile for control (noharvest) was sampled at months 2 and 24. The soil samples were air-dried for 7 days, after which the air-dried soil was crushed by using pestle and mortar, and sieved into
$2.0 \mathrm{~mm}$ size using Endecotts 2.0-mm siever (Endecotts Limited, London, UK).

\section{Statistical Analysis}

All data were analyzed with analysis of variance (ANOVA) using SAS statistical software package, Version 9.4 (SAS Institute, North Carolina State University, USA). For significant treatment effects $(p<0.05)$, Tukey's test was used to separate the treatment means.

\section{RESULTS AND DISCUSSION}

ANOVA showed there was no significant effect of harvesting $M$. bracteata on any of the soil physicochemical properties (Table

Table 4

Methods used to determine the soil physicochemical properties

\begin{tabular}{|c|c|}
\hline Property & Method \\
\hline $\mathrm{pH}\left(\mathrm{H}_{2} \mathrm{O}\right)$ & $\begin{array}{l}\text { Soil water ratio 1:2.5 (Mc Lean, 1982) and analyzed using } \\
\text { MeterLab }{ }^{\circledR} \text { PHM standard pH meter (Radiometer Analytical, Copenhagen, } \\
\text { Denmark) }\end{array}$ \\
\hline $\mathrm{CEC}\left(\mathrm{cmol}_{+} \mathrm{kg}^{-1}\right)$ & $\begin{array}{l}\text { Leaching method (Thomas, 1982), and the extractant is analyzed using } \\
\text { PerkinElmer Atomic Absorption Spectrophotometer PinAAcle } \\
\text { (PerkinElmer Inc., USA) }\end{array}$ \\
\hline Total $\mathrm{C}$ and $\mathrm{N}(\%)$ & $\begin{array}{l}\text { Analyzed using LECO TruMac }{ }^{\circledR} \text { CNS Auto Analyzer Version 1.1x. } \\
\text { (LECO Corporation, USA) }\end{array}$ \\
\hline $\begin{array}{l}\text { Available P } \\
\left(\mathrm{cmol}_{+} \mathrm{kg}^{-1}\right)\end{array}$ & $\begin{array}{l}\text { Bray and Kurtz no. } 2 \text { extracting solution (Olsen \& Sommers, 1982), and } \\
\text { the extractant is analyzed using XYZ Auto Sampler ASX - 520 Series } \\
\text { (SD Acquisition, Inc., USA) }\end{array}$ \\
\hline $\begin{array}{l}\text { Exchangeable } \mathrm{K} \\
\left(\mathrm{cmol}_{+} \mathrm{kg}^{-1}\right)\end{array}$ & $\begin{array}{l}\text { Leaching method (Thomas, 1982), and the extractant is analyzed using } \\
\text { XYZ Auto Sampler ASX - } 520 \text { Series (SD Acquisition, Inc., USA) }\end{array}$ \\
\hline $\begin{array}{l}\text { Exchangeable } \mathrm{Ca} \text { and } \mathrm{Mg} \\
\left(\mathrm{cmol}_{+} \mathrm{kg}^{-1}\right)\end{array}$ & $\begin{array}{l}\text { Leaching method (Thomas, 1982), and the extractant is analyzed using } \\
\text { PerkinElmer Atomic Absorption Spectrophotometer PinAAcle } \\
\text { (PerkinElmer Inc., USA) }\end{array}$ \\
\hline Texture & Pipette method (Teh \& Jamal, 2006) \\
\hline $\begin{array}{l}\text { Bulk density }\left(\mathrm{Mg} \mathrm{m}^{-3}\right) \\
\text { Volumetric water content }(\%) \\
\text { Porosity }(\%)\end{array}$ & Core method (Teh \& Jamal, 2006) \\
\hline Aggregate stability (\%) & Wet sieving (Teh \& Jamal, 2006) \\
\hline $\begin{array}{l}\text { Mean weight diameter } \\
\text { (aggregation) }(\mathrm{mm})\end{array}$ & Dry sieving (Teh \& Jamal, 2006) \\
\hline
\end{tabular}


5) or on any of the legume's biomass quality properties. Only the legume's biomass weight, leaf area, and $\mathrm{N}, \mathrm{Ca}$, and $\mathrm{Mg}$ plant contents were significantly affected by the harvesting treatments.

Cumulative biomass increased with increasing harvesting frequencies (Figure 1a). However, the standing biomass and leaf area decreased substantially (Figure $1 \mathrm{~b}$ and c). Mucuna bracteata harvested once every two (HF 2), four (HF 4), six (HF 6), and twelve (HF 12) months obtained biomass quantities ranging between 7.7 to $24.5 \mathrm{tha}^{-1}$ $\mathrm{yr}^{-1}$. Recall that HF 2 denotes harvesting

Table 5

Mean ( \pm std. error) of soil physicochemical properties at 0-15 and 15-30 cm soil depths at the end of the field experiment (month 24)

\begin{tabular}{|c|c|c|c|c|c|c|}
\hline \multirow[b]{2}{*}{ Property } & \multirow{2}{*}{$\begin{array}{c}(\mathrm{cm}) \\
\text { Depth }\end{array}$} & \multicolumn{5}{|c|}{ Treatments } \\
\hline & & HF 0 & HF 2 & HF 4 & HF 6 & HF 12 \\
\hline $\mathrm{C}$ & $0-15$ & $2.45 \pm 0.02$ & $2.43 \pm 0.02$ & $2.40 \pm 0.03$ & $2.39 \pm 0.03$ & $2.41 \pm 0.03$ \\
\hline$(\%)$ & $15-30$ & $2.42 \pm 0.01$ & $2.42 \pm 0.01$ & $2.42 \pm 0.01$ & $2.43 \pm 0.01$ & $2.41 \pm 0.01$ \\
\hline $\mathrm{N}$ & $0-15$ & $0.15 \pm 0.01$ & $0.15 \pm 0.01$ & $0.14 \pm 0.02$ & $0.16 \pm 0.02$ & $0.15 \pm 0.02$ \\
\hline$(\%)$ & $15-30$ & $0.15 \pm 0.02$ & $0.15 \pm 0.03$ & $0.15 \pm 0.03$ & $0.13 \pm 0.03$ & $0.16 \pm 0.03$ \\
\hline $\mathrm{P}$ & $0-15$ & $3.96 \pm 0.35$ & $3.70 \pm 0.34$ & $3.36 \pm 0.30$ & $3.18 \pm 0.26$ & $3.42 \pm 0.28$ \\
\hline$\left(\mathrm{mg} \mathrm{kg}^{-1}\right)$ & $15-30$ & $3.21 \pm 0.17$ & $3.12 \pm 0.17$ & $3.09 \pm 0.17$ & $2.89 \pm 0.10$ & $2.83 \pm 0.09$ \\
\hline $\mathrm{K}$ & $0-15$ & $0.13 \pm 0.01$ & $0.12 \pm 0.01$ & $0.08 \pm 0.02$ & $0.13 \pm 0.01$ & $0.10 \pm 0.02$ \\
\hline$\left(\mathrm{cmol}_{+} \mathrm{kg}^{-1}\right)$ & $15-30$ & $0.11 \pm 0.03$ & $0.13 \pm 0.02$ & $0.10 \pm 0.01$ & $0.15 \pm 0.03$ & $0.16 \pm 0.03$ \\
\hline $\mathrm{Ca}$ & $0-15$ & $0.30 \pm 0.06$ & $0.33 \pm 0.08$ & $0.34 \pm 0.08$ & $0.31 \pm 0.08$ & $0.29 \pm 0.09$ \\
\hline$\left(\mathrm{cmol}_{+} \mathrm{kg}^{-1}\right)$ & $15-30$ & $0.40 \pm 0.03$ & $0.34 \pm 0.03$ & $0.31 \pm 0.03$ & $0.33 \pm 0.04$ & $0.29 \pm 0.04$ \\
\hline $\mathrm{Mg}$ & $0-15$ & $0.25 \pm 0.03$ & $0.21 \pm 0.01$ & $0.22 \pm 0.03$ & $0.24 \pm 0.04$ & $0.23 \pm 0.04$ \\
\hline$\left(\mathrm{cmol}_{+} \mathrm{kg}^{-1}\right)$ & $15-30$ & $0.19 \pm 0.03$ & $0.11 \pm 0.04$ & $0.12 \pm 0.04$ & $0.14 \pm 0.04$ & $0.12 \pm 0.06$ \\
\hline CEC & $0-15$ & $9.72 \pm 1.19$ & $9.98 \pm 1.18$ & $9.95 \pm 1.19$ & $9.91 \pm 1.12$ & $10.53 \pm 1.10$ \\
\hline$\left(\mathrm{cmol}_{+} \mathrm{kg}^{-1}\right)$ & $15-30$ & $4.48 \pm 0.27$ & $4.88 \pm 0.32$ & $4.88 \pm 0.35$ & $4.75 \pm 0.34$ & $4.85 \pm 0.33$ \\
\hline \multirow[t]{2}{*}{$\mathrm{pH}\left(\mathrm{H}_{2} \mathrm{O}\right)$} & $0-15$ & $4.86 \pm 0.03$ & $4.80 \pm 0.03$ & $4.78 \pm 0.05$ & $4.72 \pm 0.05$ & $4.76 \pm 0.05$ \\
\hline & $15-30$ & $4.66 \pm 0.03$ & $4.60 \pm 0.03$ & $4.55 \pm 0.04$ & $4.49 \pm 0.04$ & $4.51 \pm 0.04$ \\
\hline Bulk density & $0-15$ & $1.49 \pm 0.07$ & $1.39 \pm 0.06$ & $1.47 \pm 0.09$ & $1.46 \pm 0.06$ & $1.40 \pm 0.08$ \\
\hline$\left(\mathrm{Mg} \mathrm{m}^{-3}\right)$ & $15-30$ & $1.54 \pm 0.06$ & $1.52 \pm 0.04$ & $1.52 \pm 0.03$ & $1.52 \pm 0.06$ & $1.53 \pm 0.11$ \\
\hline Aggregate & $0-15$ & $25.4 \pm 0.10$ & $30.0 \pm 0.32$ & $23.2 \pm 0.29$ & $22.8 \pm 0.22$ & $25.5 \pm 0.26$ \\
\hline stability (\%) & $15-30$ & $25.1 \pm 0.09$ & $28.4 \pm 0.31$ & $22.5 \pm 0.30$ & $22.7 \pm 0.17$ & $26.8 \pm 0.27$ \\
\hline Porosity & $0-15$ & $45.8 \pm 0.15$ & $47.1 \pm 0.19$ & $44.3 \pm 0.33$ & $44.6 \pm 0.23$ & $47.2 \pm 0.27$ \\
\hline$(\%)$ & $15-30$ & $46.8 \pm 0.11$ & $46.8 \pm 0.13$ & $47.3 \pm 0.16$ & $46.4 \pm 0.20$ & $46.8 \pm 0.35$ \\
\hline Aggregation & $0-15$ & $3.51 \pm 0.02$ & $3.40 \pm 0.02$ & $3.51 \pm 0.03$ & $3.54 \pm 0.05$ & $3.63 \pm 0.05$ \\
\hline$(\mathrm{mm})$ & $15-30$ & $3.50 \pm 0.02$ & $3.60 \pm 0.04$ & $3.60 \pm 0.04$ & $3.51 \pm 0.03$ & $3.48 \pm 0.05$ \\
\hline Soil water & $0-15$ & $36.0 \pm 0.2$ & $34.6 \pm 0.6$ & $36.2 \pm 0.6$ & $36.5 \pm 0.4$ & $35.8 \pm 0.5$ \\
\hline$\left(\mathrm{m}^{3} \mathrm{~m}^{-3}\right)$ & $15-30$ & $35.7 \pm 0.4$ & $35.3 \pm 0.9$ & $35.2 \pm 0.6$ & $34.0 \pm 0.5$ & $37.2 \pm 0.7$ \\
\hline
\end{tabular}

For a given soil property and soil depth, ANOVA revealed no significant effect $(\mathrm{p}>0.05)$ by all the harvesting frequency treatments (HF $n$ treatment indicates harvest once every $n$ months, and HF 0 is the control, without harvest) 
done once every 2 months (therefore, months (HF 6 and HF 12). Harvesting once most frequent), and on the other extreme, after every two months (HF 2) yielded the treatment HF 12 denotes harvesting done highest biomass followed by HF 6, HF 4 , once every 12 months (therefore, least frequent). Without harvest (control; HF and HF 12.

Similar findings were also observed 0 ), the biomass was comparable to that from other studies, such as on the giant harvested once after every six and twelve reed (Arundo donax L.) (Dragoni et al.,

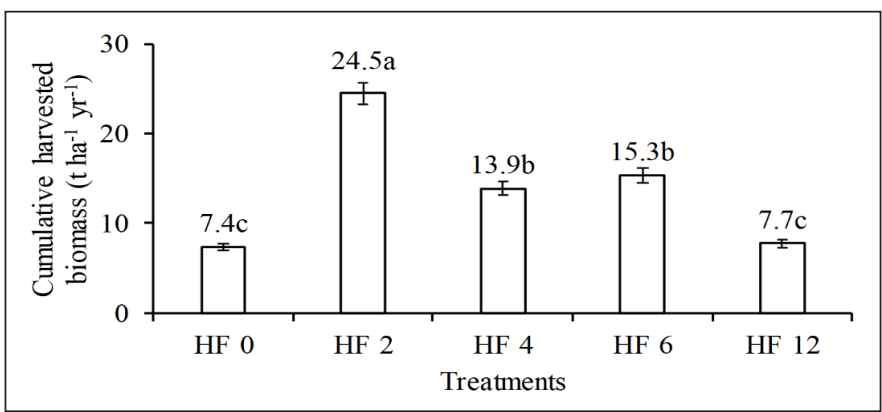

(a)

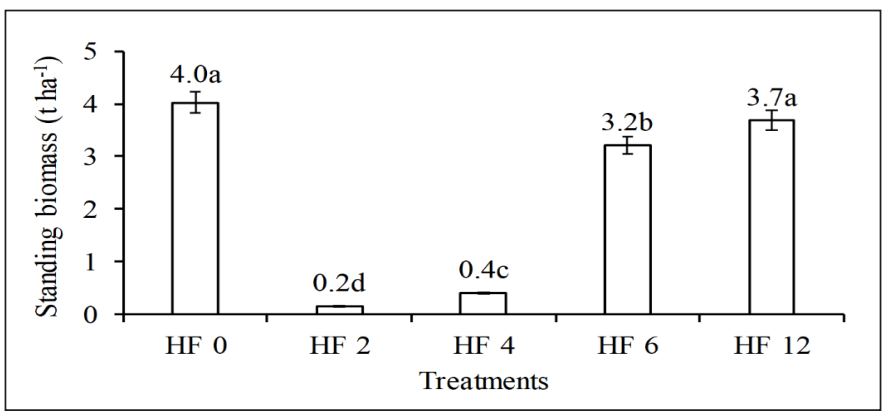

(b)

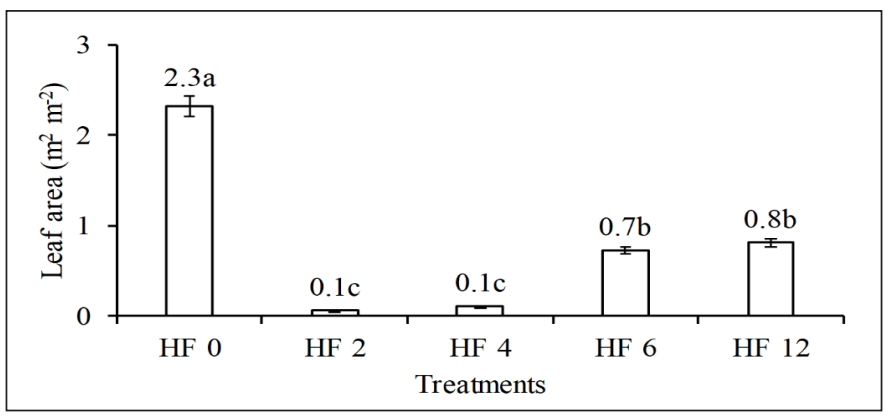

(c)

Figure 1. Mean ( \pm S.E) at month 24 of Mucuna bracteata: (a) cumulative harvested biomass, (b) standing biomass, and (c) leaf area. For the same property, means with the same letter are not significantly different from one another $(p>0.05)$ (Note. HF $n$ treatment indicates harvest once every $n$ months; HF 0 is the control, without harvest) 
2015), King Napier grass (Lounglawan et al., 2014), cassava (Hue et al., 2012), soybean (Aqeel, 2011), ryegrass/white clover swards (Vinther, 2006), and Pueraria lobata (Willd.). Terrill et al. (2003) affirmed that the more frequent the harvesting, the more cumulative crop biomass weights were obtained but the lower the standing biomass weights and leaf area. Figure $1 \mathrm{~b}$ shows that at month 24 the above ground standing biomass for HF 2 and HF 4 were greatly decreased by 94 and $89 \%$, respectively, compared with HF 0, HF 6, and HF 12. Both HF 6 and HF 12 were slightly smaller than HF 0 by about 9 and $20 \%$, respectively. Similarly to the standing biomass trend, the leaf area also showed a similar trend (Figure 1c).

The leaf area greatly decreased for HF 2 and HF 4 by 86 and $96 \%$, respectively, compared with HF 0, HF 6, and HF 12. There was not much difference in leaf area between HF 6 and HF 12; however, they still decreased by 69 and $65 \%$, respectively, compared with HF 0 . Without harvest (HF 0 ), the standing biomass and leaf area of $M$. bracteata were higher than the other harvesting frequencies.

The biomass growth recovery was expressed, in percentage, as the ratio between the current and previous weights of standing biomass harvested. This measure indicates relatively how much, in percentage, new aboveground biomass had developed since the previous harvest. Recovery rates smaller and larger than $100 \%$ indicate that the standing biomass weights at current harvest are, respectively, smaller and larger than the weights at previous harvest. Figure 2 shows the biomass recovery decreased quickly in the order of HF $2>\operatorname{HF} 4>\operatorname{HF} 6>\operatorname{HF} 12$. The more frequent the harvest, the lower the biomass recovery. For instance, HF 2's the final biomass recovery was $0.7 \%$, but for HF 4, HF 6, and HF 12, their final biomass recovery rates were at $2.8,20.6$, and $47.6 \%$, respectively. HF 0 instead had an increased biomass recovery from $18.2 \%$ initially to $54.6 \%$ in the final month.

The trends for total biomass $\mathrm{N}, \mathrm{Ca}$, and $\mathrm{Mg}$ harvested were generally the opposite of the respective biomass nutrient contents (Figure 3). The more frequent the harvest, the higher the total biomass nutrient harvested, but the lower the biomass nutrient content. Harvesting $M$. bracteata affected its biomass $\mathrm{N}, \mathrm{Ca}$, and $\mathrm{Mg}$ contents, which subsequently caused a difference in their total amount of nutrients harvested, as indicated in Figure 3. Without harvest (HF 0), the nutrient contents and nutrient harvested $(\mathrm{N}, \mathrm{Ca}$, and $\mathrm{Mg}$ ) were always the lowest compared with the other harvesting frequencies.

The biomass $\mathrm{N}$ content generally increased with decreasing harvesting frequency, in the order of HF $0<$ HF $2=$ HF $12<$ HF $4<$ HF 6 . But total biomass $\mathrm{N}$ harvested decreased in the opposite direction, in the order of HF $2>\mathrm{HF} 4>$ HF $6>$ HF $0>$ HF 12. N concentration in M. bracteata ranged between 2.3 to $3.2 \%$, which was lower compared with other legumes $(>3 \%$ of $\mathrm{N})$, as reported by Mills and Jones (1996) as well as Vose (1963). The concentration of $\mathrm{N}$ in leaves does not often correlate with the growth and yield of a 


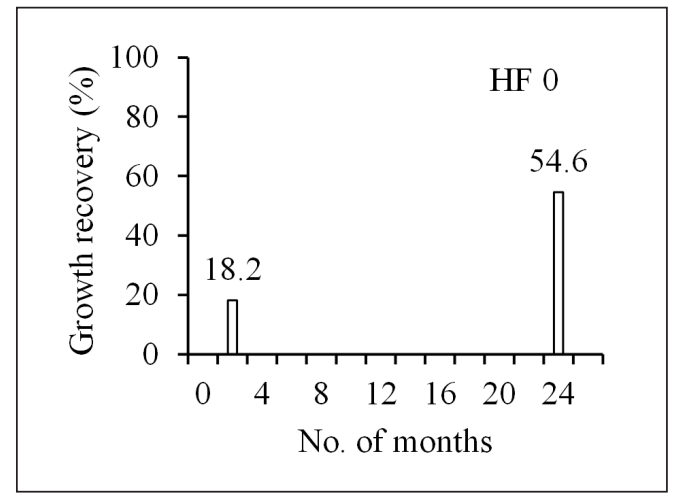

(a)

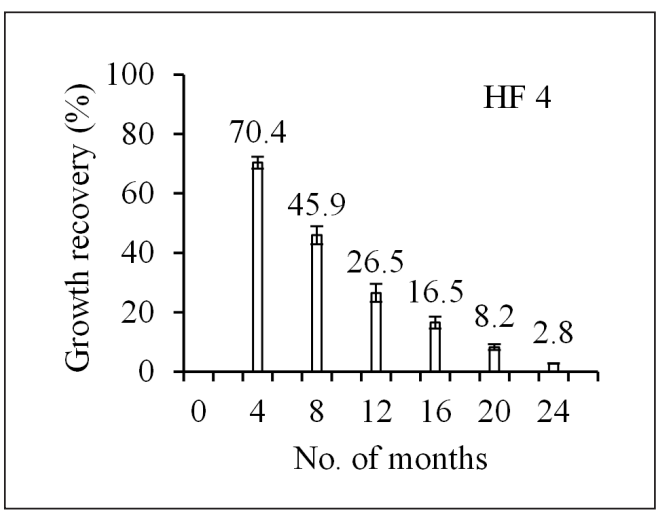

(c)

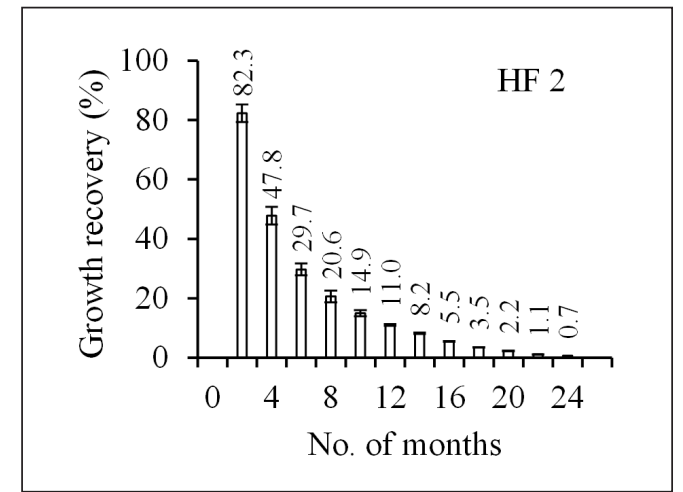

(b)

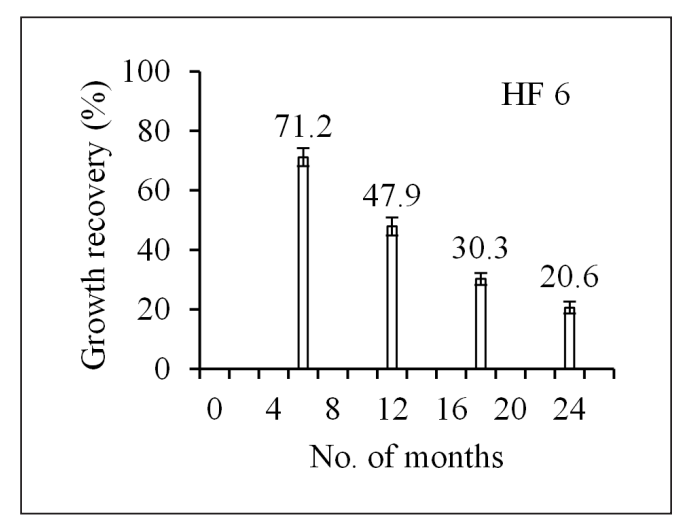

(d)

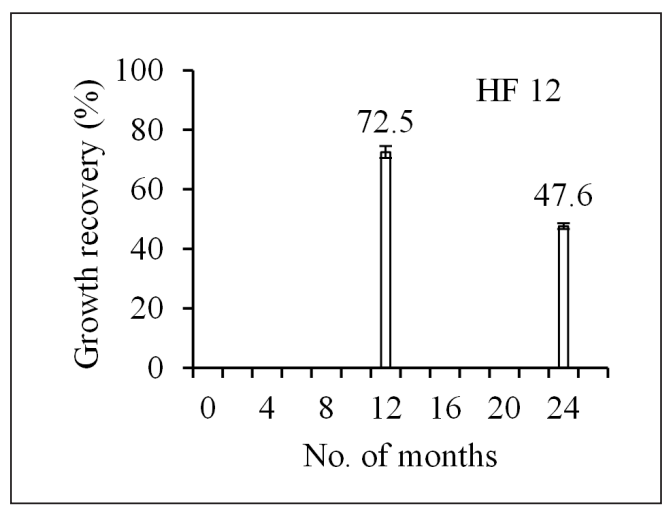

(e)

Figure 2. Growth recovery of Mucuna bracteata for all harvesting frequencies (Note. HF $n$ treatment indicates harvest once every $n$ months; HF 0 is the control, without harvest) 


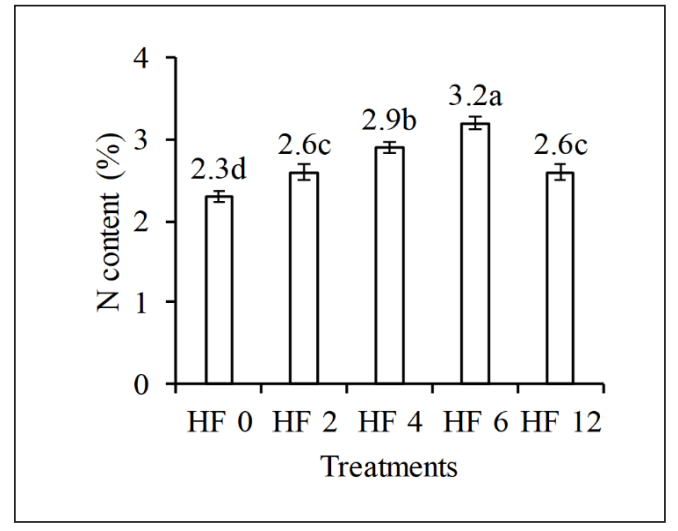

(a)

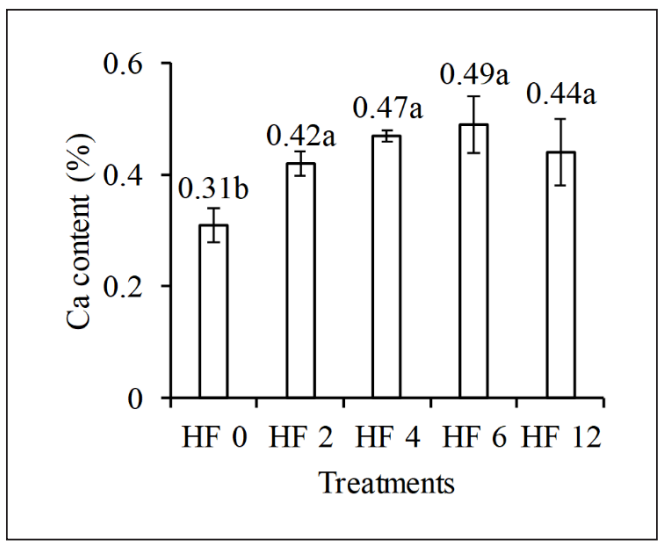

(c)

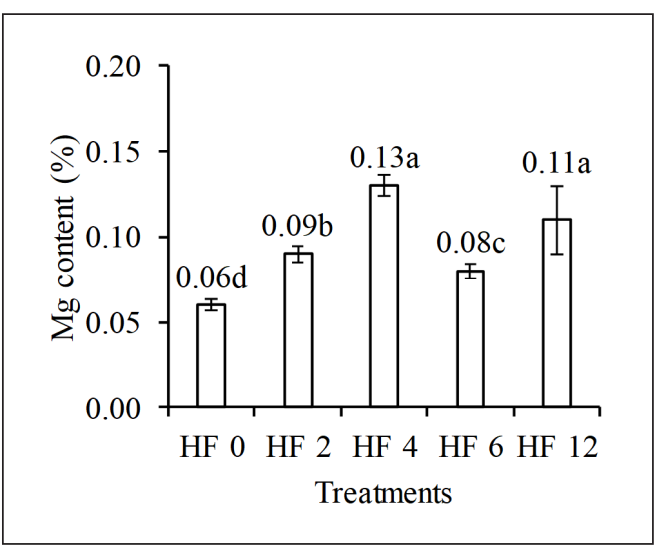

(e)

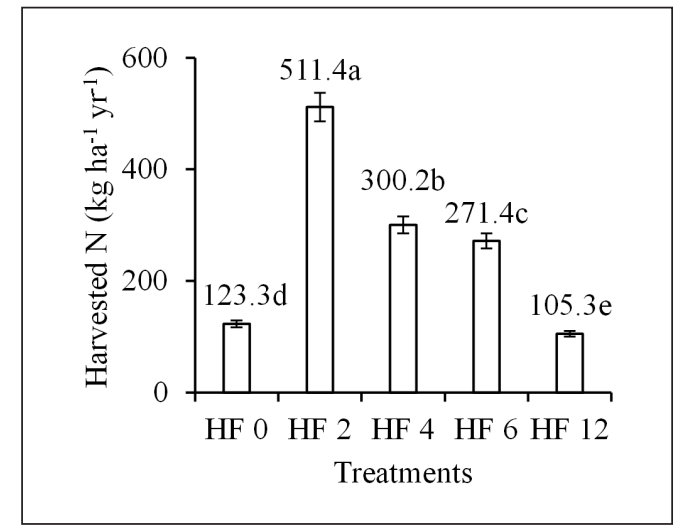

(b)

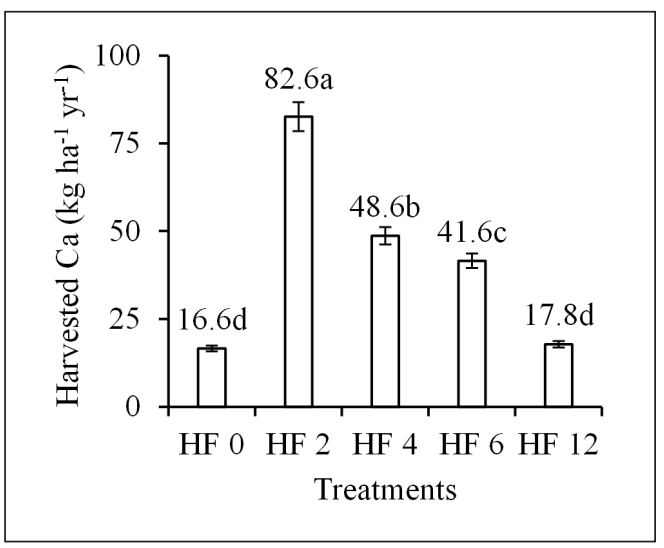

(d)

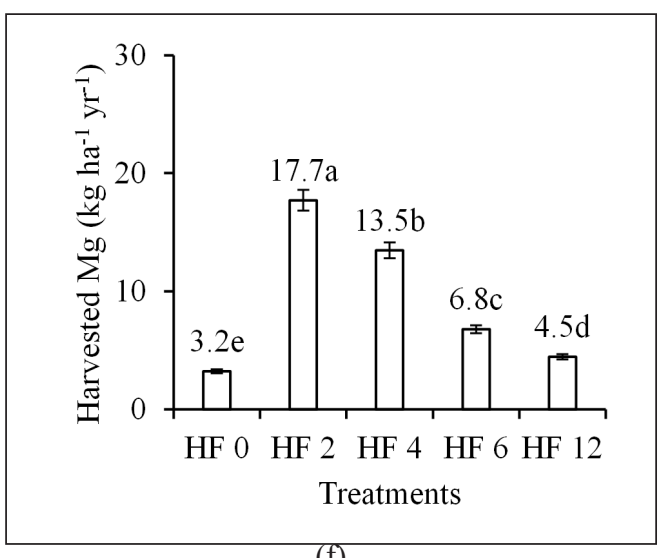

(f)

Figure 3. Mean ( \pm S.E) Mucuna bracteata's N, Ca, and Mg contents and nutrients harvested (Note. HF $n$ treatment indicates harvest once every $n$ months; HF 0 is the control, without harvest) 
plant. It is instead more correlated with plant maturity stages in the leaf, stem (stolon), and roots. This also depends on the plant type, whether the plant is annual, biennial, or perennial (Marschner, 2012).

Harvesting would remove most of the aboveground parts of $M$. bracteata, and this would indirectly influence the legume's maturity, assimilate allocation (photosynthesis, translocation, deposition, and accumulation), growth (vegetative), and the nutrient contents. At the early plant growth stage, $\mathrm{N}$ concentration in the plant would be high. Results previously showed that the more frequent $M$. bracteata was harvested, the lower the standing biomass and leaf area (Figure 1). More frequent removal of biomass meant there was relatively younger to old plant parts, and thus, more $\mathrm{N}$ was allocated to these young plant parts (Mills \& Jones, 1996; Vose, 1963; Yoneyama et al., 2003). In other words, frequent harvesting affected the maturity of $M$. bracteata. More frequent harvesting induced the legume to sprout relatively more new and young shoots and stolon.

Unlike the $\mathrm{N}$ content, there was no difference in the biomass $\mathrm{Ca}$ content between the various harvesting frequencies. HF 2 to HF 12, however, had higher Ca content than control (HF 0). This meant that harvesting $M$. bracteata, even by once every 12 months, would increase the biomass $\mathrm{Ca}$ content. And similar to the trend for $\mathrm{N}$, the total biomass $\mathrm{Ca}$ harvested decreased in the order of HF $2>\mathrm{HF} 4>\mathrm{HF} 6>\mathrm{HF} 12$ $>$ HF 0 .
$\mathrm{Mg}$ content decreased in the order of $\mathrm{HF}$ $4=\mathrm{HF} 12>\mathrm{HF} 2>\mathrm{HF} 6$ and Mg harvested HF $2>$ HF $4>$ HF $6>$ HF 12 . This showed harvesting $M$. bracteata would affect the $\mathrm{Mg}$ content and its amount harvested, following the general trend of $\mathrm{N}$.

Several studies have been conducted on the shoots of 16 cover crop species across various soil conditions. In particular, Fageria et al. (2014) as well as Reuter and Robinson (1986) reported that, on average, the plant $\mathrm{N}$ content ranged between 2.5 and 5.0\%, the Ca content between 0.7 and $3.0 \%$, and the $\mathrm{Mg}$ content between 0.3 and $0.5 \%$. The N content of $M$. bracteata observed in this study was within the range, but for the $\mathrm{Ca}$ and $\mathrm{Mg}$ contents, they were lower than the average of the 16 cover crops, as previously mentioned. However, in this study, the biomass nutrient contents were additionally affected by biomass removal from harvesting.

Figure 4a shows that harvesting did not affect the biomass cellulose content. Cellulose content, even for the legume in the control plots, increased from between $22.9-24.6 \%$ at month 0 to between 33.4 - $35.0 \%$ at month 24 , but there was no significant difference between treatments for a given month. Figure 4b, however, shows that cellulose yield was affected by the harvesting frequencies. More frequent harvest would return more biomass amounts (Figure 1) and thus, more cellulose yields. HF 2 showed the highest quantity yielded of cellulose, followed by HF 6, HF 4, and HF 12. 


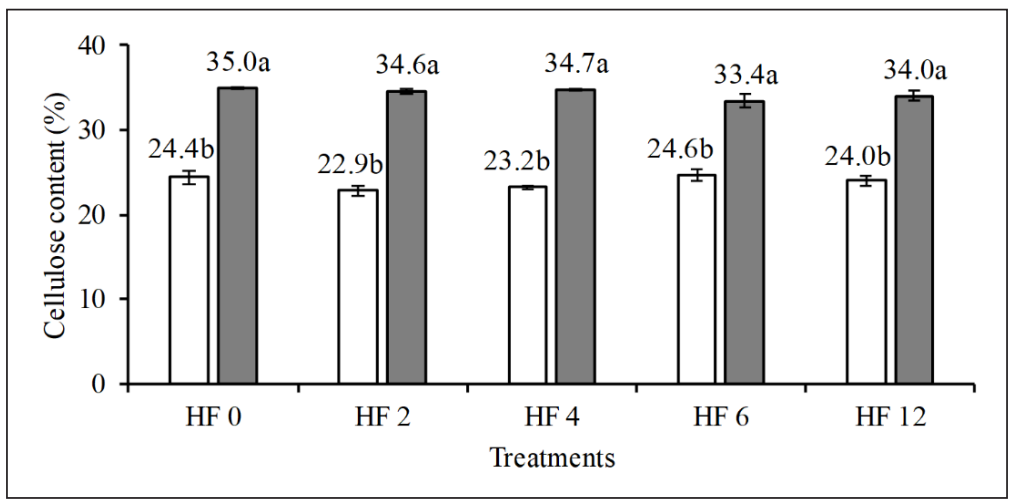

(a)

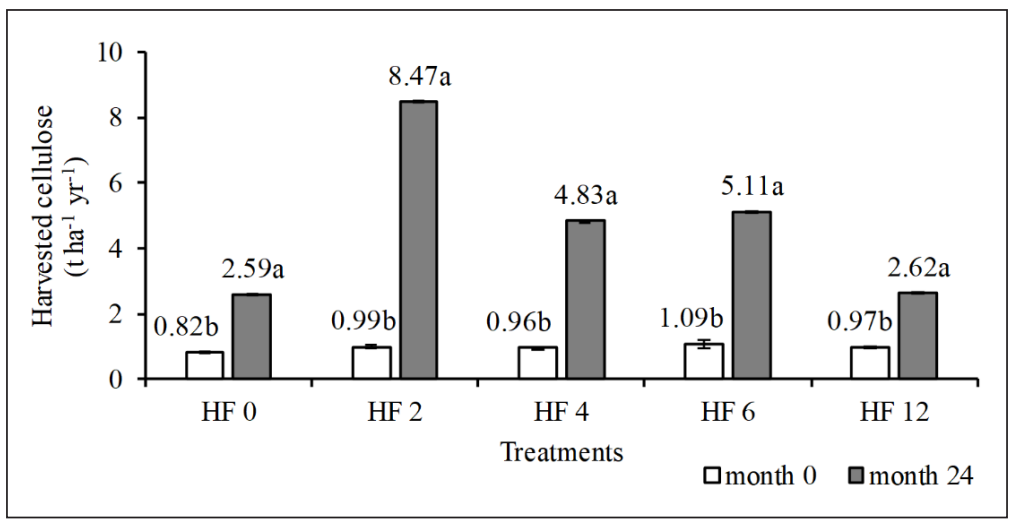

(b)

Figure 4. Mean ( \pm S.E) Mucuna bracteata's cellulose: a) content and b) yield (harvested quantity). For the same treatment, means the same letter are not significantly different from one another $(p>0.05)$ (Note. HF $n$ treatment indicates harvest once every $n$ months; HF 0 is the control, without harvest)

Similarly to other common legumes, such as $P$. javanica, C. pubescens, $C$. caeruleum, and $C$. mucunoides, harvesting M. bracteata would cause the legume to produce relatively more new and young shoots and stolon (K. J. Goh et al, 2007). During plant regrowth, cell walls are rebuilt, which would cause an increase in the plant cellulose content, more than for hemicellulose and lignin (McDonald et al., 2002). One of the major components of plant cell walls is cellulose microfibrils, comprising between 15 and $30 \%$ of the dry mass of primary walls (McQueen-Mason et al., 2003). But even without harvesting, the legume in HF 0 still showed an increase in cellulose content from month 0 to 24 . This is probably due to the increase in canopy shade (i.e., oil palm trees maturing and their canopies becoming larger and more complete in ground cover) that would inhibit more light penetration and thus increase the dieback of $M$. bracteata's older leaves and stolon so that young shoots would be produced (K. J. Goh et al., 2007), and this would synthesize more plant cellulose. 
More frequent harvesting of $M$. bracteata resulted in increasing amounts of legume biomass collected from the field. But harvesting the legume detrimentally affected the growth of the legume. Legume growth recovery decreased and never recovered even after 12 months after harvest. The leaf area of the legume was also much reduced compared with plots without harvest (HF $0)$. But although the legume growth and leaf area were reduced by harvesting, their reduction did not impact the soil properties. Soils in plots with harvest were no different than those without harvest. This could be because the soils were regularly wellfertilized under conventional management practices (Table 1) and that, despite biomass removal during harvest, the legume could still re-establish, with varying degrees of recovery, in the field (Figure 1 and 2). Results from this study suggest that $M$. bracteata could be harvested but not too frequently, such as once every two (HF 2) to four (HF 4) months, as this would greatly reduce the legume standing biomass and leaf area in the field. Instead, harvesting the legume once every six months (HF 6) is an acceptable compromise between collecting large amounts of legume biomass and having a reduced legume growth recovery and leaf area in the field, but yet not detrimentally affecting the soil properties.

\section{CONCLUSIONS}

Harvesting Mucuna bracteata affected the legume biomass but not the soil properties. The more frequent the harvest, the more biomass was obtained, but the legume standing biomass and leaf area were reduced. Despite the reduction in legume growth and leaf area in the field, harvesting the legume did not affect any of the soil physicochemical properties. The biomass $\mathrm{N}$, $\mathrm{Ca}$, and $\mathrm{Mg}$ contents were also affected by harvesting. This was due to the production of relatively more young shoots after harvesting, which would remove most of the aboveground plant parts. The cellulose content in the legume also increased for the same reasons. Results showed that too frequent harvesting (such as once every two or four months) is not recommended, as it would cause too much reduction in legume standing biomass and leaf area (despite allowing for large amounts of biomass to be collected). Instead, harvesting $M$. bracteata once every six months is recommended as this harvesting frequency provided for large amounts of legume biomass without having excessive reduction in legume growth, as compared with other harvesting frequencies, and without detrimentally affecting soil physicochemical properties.

\section{ACKNOWLEDGEMENTS}

We would like to thank Mr. Goh Kah Joo and Applied Agriculture Research Sdn. Bhd. for the research funds and field logistics; the management of Kombok Estate; Department of Land Management, UPM; Department of Crop Science, UPM; Institute of Tropical Agriculture and Food Security (ITAFoS), UPM; Department of Environment and Chemical Engineering, UPM; and Malaysian Agriculture Research and Development Institute (MARDI) for their help. 


\section{REFERENCES}

Abdul Khalil, H. P. S., Kang, C. W., Khairul, A., Ridzuan, R., \& Adawi, T. O. (2009). The effect of different laminations on mechanical and physical properties of hybrid composites. Journal of Reinforced Plastics and Composites, 28(9), 1123-1137. https://doi. org/10.1177/0731684407087755

Abdul Khalil, H. P. S., Poh, B. T., Issam, A. M., Jawaid, M., \& Ridzuan, R. (2010). Recycled polypropylene-oil palm biomass: The effect on mechanical and physical properties. Journal of Reinforced Plastics and Composites, 29(8), 1117-1130. https://doi. org/10.1177/0731684409103058

Agensi Inovasi Malaysia. (2013). National Biomass Strategy 2020: New wealth creation for Malaysia's biomass industry (Version 2.0, 2013). Agensi Inovasi Malaysia.

Aqeel, A. M. (2011). Using manual defoliation to simulate soybean rust: Effect on growth and yield formation [Unpublished Doctoral dissertation]. University of Kentucky.

Campostrini, E., \& Yamanishi, O. K. (2001). Estimation of papaya leaf area using the central vein length. Scientia Agricola, 58(1), 39-42. https:// doi.org/10.1590/S0103-90162001000100007

Chaikitkaew, S., Kongjan, P., \& Thong, S. O. (2015). Biogas production from biomass residues of palm oil mill by solid state anaerobic digestion. Energy Procedia, 79, 838-844. https://doi. org/10.1016/j.egypro.2015.11.575

Chiu, S. B., \& Basad, M. (2006). Mucuna bracteata - Biomass, litter and nutrient production. The Planter, 82(961), 247-254.

Chiu, S. B., Farida, E., \& Siow, A. (2001). Mucuna bracteata - A super legume cover crop revisited. The Planter, 77(907), 575-583.

Department of Agriculture. (2008). Panduan siri-siri tanah utama di Semenanjung Malaysia [Guide to main soil series in Peninsular Malaysia] (2nd ed.). Ministry of Agriculture and Food Industries.

Dragoni, F., o Di Nasso, N. N., Tozzini, C., Bonari, E., \& Ragaglini, G. (2015). Aboveground yield and biomass quality of giant reed (Arundo donax L.) as affected by harvest time and frequency. BioEnergy Research, 8(3), 13211331. https://doi.org/10.1007/s12155-0159598-x

Fageria, N. K., Baligar, V. C., \& Li, Y. C. (2014). Nutrient uptake and use efficiency by tropical legume cover crops at varying $\mathrm{pH}$ of an Oxisol. Journal of Plant Nutrition, 37(2), 294-311. https://doi.org/10.1080/01904167.2013.851695

Gardner, J. L., He, W., Li, C., Wong, J., Sale, K. L., Simmons, B. A., \& Tanjore, D. (2015). Calorimetric evaluation indicates that lignin conversion to advanced biofuels is vital to improving energy yields. RSC Advances, 5(63), 1092-1101. https://doi.org/10.1039/ C5RA01503K

Goh, C. S., Tan, K. T., Lee, K. T., \& Bhatia, S. (2010). Bio-ethanol from lignocellulose: Status, perspectives and challenges in Malaysia. Bioresource Technology, 101(13), 4834-4841. https://doi.org/10.1016/j.biortech.2009.08.080

Goh, K. J., Gan, H. H., \& Ng, H. C. P. (2007). Agronomy of Mucuna bracteata under oil palm. In K. J. Goh (Ed.), Mucuna bracteata: A cover crop and living green manure (pp. 45-84). Agricultural Crop Trust (ACT).

Hue, K. T., Van, D. T. T, Ledin, I., Wredle, E., \& Sporndly, E. (2012). Effect of harvesting frequency, variety and leaf maturity on nutrient composition, hydrogen cyanide content and cassava foliage yield. Asian-Australasian Journal of Animal Science, 25(12), 1691-1700. https://doi.org/10.5713/ajas.2012.12052

Idris, S. S., Rahman, N. A., Ismail, K., Alias, A. B., Rashid, Z. A., \& Aris, M. J. (2010). Investigation on thermochemical behaviour of low rank 
Malaysian coal, oil palm biomass and their blends during pyrolysis via thermogravimetric analysis (TGA). Bioresource Technology, 101(12), 4584-4592. https://doi.org/10.1016/j. biortech.2010.01.059

Kothandaraman, R., Mathew, J., Krishnakumar, A. K., Joseph, K., Jayarathnam, K., \& Sethuraj, M. R. M. (1989). Comparative efficiency of Mucuna bracteata DC and Pueraria phaseoloides Benth. on soil nutrient enrichment, microbial population and growth of Hevea. Indian Journal of Natural Rubber Research, 2, 147-150.

Lior, N. (2008). Energy resources and use: The present situation and possible paths to the future. Energy, 33(6), 842-857. https://doi.org/10.1016/j. energy.2007.09.009

Lounglawan, P., Lounglawan, W., \& Suksombat, W. (2014). Effect of cutting interval and cutting height on yield and chemical composition of King Napier grass (Pennisetum purpureum $\mathrm{x}$ Pennisetum americanum). APCBEE Procedia, 8, 27-31. https://doi.org/10.1016/j. apcbee.2014.01.075

Ludwig, C., Wochele, J., \& Jörimann, U. (2007). Measuring evaporation rates of metal compounds from solid samples. Analytical Chemistry, 79(7), 2992-2996. https://doi.org/10.1021/ac0622173

Marschner, H. (2012). Marschner's mineral nutrition of higher plants (3rd ed.). Academic Press.

Mathews, C. (1998). The introduction and establishment of a new leguminous cover crop, Mucuna bracteata under oil palm in Malaysia. The Planter, 74(868), 359-368.

McDonald, P., Edward, R. A., Greenhalgh, J. F. D., \& Morgan, C. A. (2002). Animal nutrition (6th ed.). Wiley.

McLean, E. O. (1982). Soil pH and lime requirement. In A. L. Page (Ed.), Methods of soil analysis. Part 2. Chemical and microbiological properties (2nd ed., pp. 199-224). American Society for Agronomy.
McQueen-Mason, S., Darley, C., Roberts, P., \& Jones, L. (2003). Cell growth. In B. Thomas, D. J. Murphy, \& B. G. Murray (Eds.), Encyclopedia of applied plant sciences (pp. 523-532). Academic Press.

Mills, H. A., \& Jones Jr, J. B. (1996). Plant analysis handbook II. Plant Nutrition. MicroMacro Publishing.

Olsen, S. R., \& Sommers, L. E. (1982). Phosphorus. In A. L. Page (Ed.), Methods of soil analysis. Part 2. Chemical and microbiological properties (2nd ed., pp. 403-430). American Society of Agronomy, Soil Science Society of America.

Reuter, D. J., \& Robinson, J. B. (1986). Plant analysis: An interpretation manual. CSIRO Publishing.

Saura-Calixto, F., Cañellas, J., \& Soler, L. (1983). Dietary fibre and components of the nitrogenfree extract of almond kernels. Journal of the Science of Food and Agriculture, 34(12), 14191422. https://doi.org/10.1002/jsfa.2740341216

Shuit, S. H., Tan, K. T., Lee, K. T., \& Kamaruddin, A. H. (2009). Oil palm biomass as a sustainable energy source: A Malaysian case study. Energy, 34(9), 1225-1235. https://doi.org/10.1016/j. energy.2009.05.008

Teh, C. B. S., \& Jamal, T. (2006). Soil physics analyses (Vol. 1). UPM Press.

Terrill, T. H., Gelaye, S., Mahotiere, S., Amoah, E. A., Miller, S., \& Windham, W. R. (2003). Effect of cutting date and frequency on yield and quality of kudzu in the Southern United States. Grass and Forage Science, 58(2), 178-183. https://doi. org/10.1046/j.1365-2494.2003.00369.x

Thomas, G. W. (1982). Exchangeable cations. In A. L. Page (Ed.), Methods of soil analysis. Part 2. Chemical and microbiological properties (2nd ed., pp. 159-165). American Society for Agronomy.

Van Lierop, W. M. (1976). Digestion procedures for simultaneous automated determination of $\mathrm{NH}_{4}$, 
$\mathrm{P}, \mathrm{K}, \mathrm{Ca}$ and $\mathrm{Mg}$ in plant material. Canadian Journal of Soil Science, 56(4), 425-432. https:// doi.org/10.4141/cjss76-051

Vinther, F. P. (2006). Effects of cutting frequency on plant production, $\mathrm{N}$-uptake and $\mathrm{N}_{2}$ fixation in above- and below-ground plant biomass of perennial ryegrass-white clover swards. Grass and Forage Science, 61(2), 154-163. https://doi. org/10.1111/j.1365-2494.2006.00519.x

Vose, P. B. (1963). Varietal differences in plant nutrition. Herbage Abstracts, 33(1), 1-13.
Yoneyama, T., Ito, O., \& Engelaar, W. M. H. G. (2003). Uptake, metabolism and distribution of nitrogen in crop plants traced by enriched and natural ${ }^{15} \mathrm{~N}$ : Progress over the last 30 years. Phytochemistry Reviews, 2, 121-132. https:// doi.org/10.1023/B:PHYT.0000004198.95836.ad

Zarate-Valdez, J. L., Whiting, M. L., Lampinen, B. D., Metcalf, S., Ustin, S. L., \& Brown, P. H. (2012). Prediction of leaf area index in almonds by vegetation indexes. Computers and Electronics in Agriculture, 85, 24-32. https://doi. org/10.1016/j.compag.2012.03.009 
